\title{
Leadership Styles and Employees' Productivity: A Case Study of Public University Libraries of Jamshoro City, Sindh Province, Pakistan
}

\section{Tanveer Ahmed", Chaojun Yang1, Hongjuan Yang1, Liaquat Ali Rahoo'2, Salman Mahmood", Bakaye Poudiougo ${ }^{1}$}

\author{
${ }^{1}$ Faculty of Management \& Economics, Kunming University of Science \& Technology, Kunming, China \\ ${ }^{2}$ MUET Library and Online Information Center, Mehran University of Engineering \& Technology, Jamshoro, Pakistan \\ Email: tmsurahio82cs@hotmail.com, yangcj84@163.com,939738277@qq.com, liaquatalirahoo2003@gmail.com, \\ salmankmust@gmail.com, bakayep88@yahoo.com
}

How to cite this paper: Ahmed, T., Yang, C. J., Yang, H. J., Rahoo, L. A., Mahmood, S., \& Poudiougo, B. (2021). Leadership Styles and Employees' Productivity: A Case Study of Public University Libraries of Jamshoro City, Sindh Province, Pakistan. Open Journal of Leadership, 10, 230-240.

https://doi.org/10.4236/ojl.2021.103015

Received: July 12, 2021

Accepted: September 27, 2021

Published: September 30, 2021

Copyright $\odot 2021$ by author(s) and Scientific Research Publishing Inc. This work is licensed under the Creative Commons Attribution International License (CC BY 4.0).

http://creativecommons.org/licenses/by/4.0/

\section{(c) (i) Open Access}

\begin{abstract}
The main purpose of this research study is to examine leadership styles (autocratic, democratic and transformational) containing along with employees' productivity in carefully chosen public university libraries of Sindh Province. So, for this purpose, the descriptive survey design is used in this study along with the nature of quantitative research methodology. The overall population for this study is comprised of two main public universities of Sindh, Pakistan. 1) University of Sindh, Jamshoro; 2) Mehran University of Engineering and Technology (MUET) Jamshoro, Sindh Province, Pakistan. The sample size for this study containing a total of thirty-one (31) library employees called librarians, which signifies the total population of academic employees called librarians in the institutes considered, was used. Data was collected through a structured questionnaire survey. The sample size for this study was thirty-one (31) respondents. Data was analyzed through SPSS software by using different statistical techniques likewise frequency, percentages, mean and standard deviation. Results for this study revealed the implementation of autocratic, democratic, and transformational leadership styles by means of the University library employees called librarians. The transformational style of leadership is largely accepted followed by democratic style. This study consistently concluded that the leadership styles of university library employees distress the efficiency of the employees under their supervision. This research study also endorsed that the formation of a better working environment, along with the adoption of good leadership styles that will absolutely develop the responsive relationship amongst the head of departments of all libraries with their subordinates.
\end{abstract}




\section{Keywords}

Libraries, University, Librarians, Employees, Leadership Styles, Staff

Productivity

\section{Introduction}

Currently in this modern world, the level of commitment of workers is critical for the survival and continuity of any organization (Azeez et al., 2016). For any organization to function effectively, the organization must be able to retain the qualified and committed workforce. However, this is not the case in many organizations today, as evidence has shown that it is becoming difficult for managers to retain their workers and this is increasing the rate of the turnover intention among employees across various sectors. In fact, (Caglar \& Duarte, 2019) pointed out that "managers now spend $10 \%-20 \%$ of their time recruiting and training new hires in high turnover service businesses". Although in a developing country like Nigeria and with the uncertainty brought about by rising unemployment rates even among the vibrant youth population, it can be said that turnover may not be as high as recorded in developed countries, however, there is an intent to leave an organization for another due to one or a combination of several factors. This is what is referred to in the literature as "turnover intentions". (Kumar, 2011) noted that "turnover is a critical human resource issue in all sectors of the economy which affects productivity, product and service quality, and profitability" (Azeez et al., 2016). The intention to leave one's place of work is a result of several factors. (Bandhanpreet et al., 2013) declared that turnover purpose is a multifaceted wonder that hinge on several factors; (Omeluzor et al., 2017) noted that these indicators are "age, gender, tenure, designation, experience, compensation, education, nature of employment are predictors of turnover intentions of employees in organizations (p. 5)".

Leadership styles partake dissimilar possessions on the feelings of targeted supporters besides the greatest operative style a leader can use is a good mix that is customized to the situation. In line with this statement, leadership style adopted by any librarian should be guided by the beliefs, values and preferences, culture, norms, the dos and the don'ts of the organization or parent body. According to (Pearce \& Robinson, 2005), the ability of the management team to achieve what the library is set out to achieve is library is the sequel to the leadership style adopted. The most fundamental issue about leadership is how to mobilize others (sub-ordinates) for getting additional normal activities completed in the organization. Leadership is basically the practice implemented by leaders for transmuting values into activities, revelations into realism, complications into inventions, distinctiveness into harmony and risks into rewards (Kouzes \& Posner, 2002). Leadership provides the plentiful opportunity for people to turn challenging tasks into landmark success through their inspiration. 
Furthermore, (Belete, 2018) identified factors that may influence the turnover intention, such as leadership styles, organizational culture, promotion opportunities, salary, and job satisfaction. Employee's intention to leave their current place of work has become a critical issue for organizations irrespective of size, where they are, and what they do (Long et al., 2012). This means that the turnover intention among employees cuts across sectors and organizations. The library as an organization has its fair share of turnover intention among its staff. Studies, such as (Idiegbeyan-Ose et al., 2018), have shown the growth of turnover issues among Nigerian librarians in public and private universities in recent times.

The main purpose of this study is to examine the leadership styles (autocratic, democratic, and transformational) along with employees' productivity in nominated university library personals that are working in the University of Sindh and in Mehran University of Engineering and Technology, Jamshoro City, Sindh Province, Pakistan.

\section{Literature Review}

Libraries as always considered as dynamic institutions can at least have professional and visionary leaders because they must be organized for facing innumerable crises and fluctuations in the future. The features of leaders become the main foundation in the performance of their subordinates to achieve success. The accomplishment of this process is a distinct attainment in preserving the sustainability of the institution (Akparobore \& Omosekejimi, 2020). Librarians are fully accountable intended for receiving, organizing, managing and issuing library resources also confirming that all library supplies are fully able to satisfy the information requirements of all the users. As librarians in university libraries are responsible for providing support to their parent institutions. Their work related activities may demand a degree that is relevant to a particular subject area. The role of Librarians in the library can be regarded as people-focused role that require individuals to adequately manage the information materials that are acquired in the library with the intention of satisfying the information needs of library users. The library is set out to render information services, hence, the job-related activities of library staff are centered on the various library and information services that are rendered in the library (Aina, 2016). On the other hand, the leadership characteristics can also increase the potential, as well as innovation, and a sense of responsibility for subordinates in their work. In that sense, librarians can work and increase their productivity from the characteristics of the leadership who are the role models (Wilson, 2020).

There are numerous forms of leadership styles such as transformational leadership, transactional leadership, autocratic, democratic leadership, participatory leadership styles. The leadership styles selected for this research study are: autocratic, democratic and transformational. The scope of this research study contains Public University Libraries of Jamshoro City. The foremost research objective is to assess leadership styles (autocratic, democratic transformational) and employees (focused on librarian) productivity in public university libraries 
of Jamshoro City, Sindh Province, Pakistan. (Purwanto et al., 2020) specified that democratic leaders are individuals who emphasize on group debates besides group involvement consequently it definitely stimulates follower working act. Hence, democratic leadership style is used to expand executive performance as well as organizational efficacy. The power of autocratic leaders forces their followers to carry out services and strategies according to their path. Conferring to the perception of autocratic leadership similarly acknowledged as leadership Authoritarian style, autocratic leaders are fewer imaginative and only indorse biased communiqué. This significantly stimulates the motivation as well as fulfilment level of dependents. The autocratic leadership style is always acknowledged to be operative for the short tenure. The autocratic leadership bounds the workplace of socialization also mutual communication. Autocratic leadership correspondingly leads towards administrative conflicts partaking harmful influence on total organizational performance (Igbaekemen, et al., 2015). Bestowing to (Purwanto et al., 2020) the leaders are very devoted to perusing their methods and procedures but not to their individuals. This way is not very operative, the situation doesn't lead to the expansion and inspiration of dependents. These leaders only emphasize their everyday jobs on being methodically accomplished (Germano, 2010). Rendering to (Purwanto et al., 2020) transformational leadership style emphasizes evolving supporters as well as in view of their desires. Leaders who emphasize on transformational leadership exactly focus on evolving the inclusive worth of subordinate systems, emerging standards, skills along with motivation levels. Transformational leadership acts as a durable connection among supporters and leaders, on the way to grow a strong considerate associated with the level of inspiration, standards and benefits.

Organizations in the modern era are faced with unrestricted and rapid changes in their processes and procedures. This has posed serious challenges to the sustainability of these organizations. For instance, (Azeez et al., 2016) Human capital is the major aspect of the organization that is affected by these changes. It should be noted that human capital is the pivot that drives effectiveness in organizations (Idiegbeyan-Ose et al., 2018). In fact, human capital determines to a large extent the value of the organizations and their level of productivity. (Omeluzor et al., 2017) noted that in this era of highly competitive business environments, "talented employees are considered as key resources". The ability of organizations to retain these employees has been seen as a critical challenge to 21 st-century organizations. In fact, many employees have shown the intention to change their workplaces to organizations with better career prospects and welfare packages. This desire to leave one place of work for another is called "turnover intention". (Belete, 2018) defined "turnover intention" as "employees' willingness or attempts to leave the current workplace voluntarily". Correspondingly, (Idiegbeyan-Ose et al., 2018) defined "turnover intention" basically by means of "the rate to which a member of staff is willing to leave a particular organization” (p. 2). Turnover intention possibly will even mean an employee's consideration or thinking of quitting a job. (Bandhanpreet et al., 2013) reported 
that in Zimbabwe the "majority of academic librarians (80\%) consider employment outside Zimbabwe as a vibrant option to their current state of affairs". Several studies have shown that there are many variables that could lead people to quit their job. Some of them are; job satisfaction, organizational culture, organizational commitment, leadership styles, pay satisfaction, promotion opportunities, work-family conflict, and so forth (Idiegbeyan-Ose et al., 2018). The findings of these studies established a connection between leadership styles, employee retention, and employee performance. Also concluded that effective leadership style is crucial for achieving organizational goals.

Correspondingly, (Idiegbeyan-Ose et al., 2018) established that a relationship exists between leadership style and turnover intention. Other studies show that salary or financial benefit is a major consideration both for employers and employees (Omeluzor et al., 2017). Hence, noted that for employees, pay is of obvious importance in terms of satisfying their economic needs. Libraries, regardless of the type and size are seen as centers for the provision and utilization of quality information and information resources. According to (Segun-Adeniran, 2015), libraries remain the hubs of information and knowledge, without which the transmission of information and knowledge will not be complete. These libraries occupy an important place in the advancement of national integrity and protection of cultural heritage. The university library, being the library attached to a university is an organized institution headed by a librarian (addressed as the University Librarian), and is set up with outlined objectives, in line with that of the parent institution (the university) that needs to be achieved by both the employees (the staff) and university library management team (headed by the University Librarian).

\section{Research Objectives}

- To identify the leadership styles adopted by University Librarians.

- To find the amount of adoption of leadership styles by University Librarians.

- To determine the rate of staff productivity in the university libraries.

- To examine the effect of leadership styles adopted on staff productivity in the university libraries.

- To investigate the factors militating against staff productivity in the university libraries.

\section{Research Methodology}

This research study is quantitative in nature; the descriptive survey research methodology was employed. The population of this study was comprised of two main public university library employees (librarian) of Sindh Province, Pakistan. 1) University of Sindh Jamshoro; 2) Mehran University of Engineering and Technology (MUET) Jamshoro City, Sindh Province, Pakistan. A sample of thirty-one (31) academic library employees called librarians, which denotes the whole population of academic librarians in the institutions studied, was used. Data was collected using a structured questionnaire made up of two main (02) 
parts, Part A besides Part B. Part A collected the respondents' demographic variables, while Part $B$ answered the core variable questions spread across five (05) clusters along with six (06) items each, giving a total of thirty (30) item statements. Total thirty-one (31) questionnaires were distributed and all were returned back and found suitable for data analysis, thus giving a response rate of $100 \%$. The data was analyzed in SPSS version 22 using different statistical techniques likewise counts, simple percentages, mean scores and standard deviation.

\section{Results and Discussion}

This section captures and presents data generated from the field survey conducted in the course of carrying out this study.

\section{1) Universities}

In the above Chart of Figure 1: Universities shows that the demographic variables of the respondents Out of a total of thirty-one (31) respondents, result shows that MUET constitutes 11 (35\%) and UoS 20 (65\%).

\section{2) Qualifications of Respondents}

In the above chart of Figure 2: Qualification denotes qualification of respondents, result shows that respondents that constitute 26 (84\%) holds bachelor's degree, 4 (13\%) holds Master's degree, and 1 (3\%) holds doctorate degree ( $\mathrm{PhD})$.

\section{3) Experience of Working}

\section{Universities}

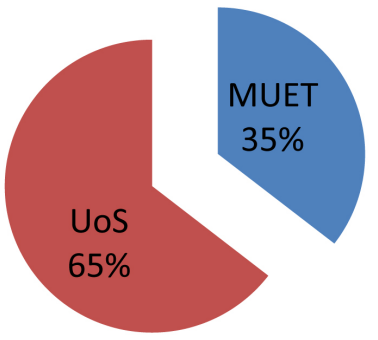

Figure 1. Universities.

\section{Qualification}
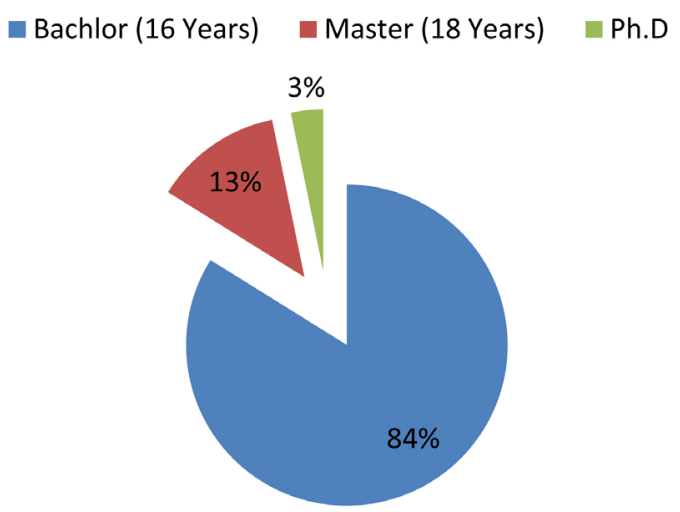

Figure 2. Qualification. 
In the above chart of Figure 3: Denotes the respondents' working experience in years, data shows that respondents with years of experience 0 - 5 years, constitutes $3(10 \%), 6$ - 10 years $6(19 \%), 11$ - 15 years 7 (23\%), 16 - 20 years 11 (35\%), and 21 years and above 4 (13\%).

\section{4) Leadership Styles Adopted by University Librarians}

According to the results of mentioned Table 1: all leadership styles clearly specified that is adopted by majority of the respondents, with the frequency of counts and percentages, that comprise autocratic leadership style with 19 (61.3\%), democratic leadership style with 20 (64.5\%), and transformational leadership style with 20 (64.5\%). From all mentioned leadership styles adopted by the libraries studied, the result shows that democratic and transformational leadership styles had the highest number of responses. Consequently, majority of the respondents rated not adopted leadership styles like bureaucratic leadership styles with 22 (71\%), laissez-fair leadership style with 25 (80.6), and transactional leadership style with 21 (67.7).

\section{5) Extent of Adoption of Leadership Styles by University Librarians}

According to the results of Table 2: the majority of the respondents rated high extent to the adoption of democratic leadership style and transformation leadership style, with a mean score and standard deviation of $2.55(0.888)$ and 2.65 (1.082), respectively. The high extent rating of items 8 and 11 is as a result of their mean ratings surpassing the criterion mean of 2.50 chosen for the study. They include: Autocratic leadership style with 2.29 (1.006), bureaucratic leadership style with 2.03 (1.048), laissez-faire leadership style with 1.77 (0.990), and transactional leadership style with 2.10 (1.044).

6) Rate of Staff Productivity of Librarians in the University Libraries

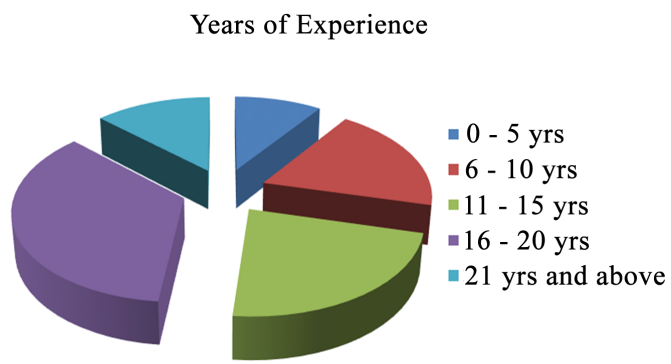

Figure 3. Experience.

Table 1. Leadership styles adopted by university librarians.

\begin{tabular}{ccccccc}
\hline S/N & Item Statements & Adopted & $\%$ & Not Adopted & $\%$ & Decision \\
\hline $\mathbf{1}$ & Autocratic leadership style & 19 & 61.3 & 12 & 38.7 & Adopted \\
$\mathbf{2}$ & Democratic leadership style & 20 & 64.5 & 11 & 35.5 & Adopted \\
$\mathbf{3}$ & Bureaucratic leadership style & 9 & 29 & 22 & 71 & Not Adopted \\
$\mathbf{4}$ & Laissez-fair leadership style & 6 & 19.4 & 25 & 80.6 & Not Adopted \\
$\mathbf{5}$ & Transformational leadership style & 20 & 64.5 & 11 & 35.5 & Adopted \\
$\mathbf{6}$ & Transactional leadership style & 10 & 32.3 & 21 & 67.7 & Not Adopted \\
\hline
\end{tabular}


Table 2. Extent of adoption of leadership styles by university librarians.

\begin{tabular}{ccccccccc}
\hline S/No & Leadership Styles & $\begin{array}{c}\text { VHE } \\
(\%)\end{array}$ & $\begin{array}{c}\text { HE } \\
(\%)\end{array}$ & $\begin{array}{c}\text { LE } \\
(\%)\end{array}$ & $\begin{array}{c}\text { VLE } \\
(\%)\end{array}$ & Mean & $\begin{array}{c}\text { St. } \\
\text { dev. }\end{array}$ & Decision \\
\hline $\mathbf{7}$ & Autocratic leadership style & -9.7 & -38.7 & -22.6 & -29 & 2.29 & 1.006 & Low Extent \\
$\mathbf{8}$ & Democratic leadership style & -16.1 & -32.3 & -41.9 & -9.7 & 2.55 & 0.888 & High Extent \\
$\mathbf{9}$ & Bureaucratic leadership style & -12.9 & -16.1 & -32.3 & -38.7 & 2.03 & 1.048 & Low Extent \\
$\mathbf{1 0}$ & Laissez-fair leadership style & -9.7 & -9.7 & -29 & -51.6 & 1.77 & 0.99 & Low Extent \\
11 & Transformational leadership style & -22.6 & -41.9 & -12.9 & -22.6 & 2.65 & 1.082 & High Extent \\
12 & Transactional leadership style & -9.7 & -29 & -22.6 & -38.7 & 2.1 & 1.044 & Low Extent \\
\hline
\end{tabular}

The result of Table 3 shows the agreement of all item statements by majority of the respondents. This is due to the fact that their mean scores surpassed the criterion mean chosen for the study. This shows that the librarians are productive in the following ways or areas: Able to work to the close of work having 3.45 (0.506), brings new ideas into the library having 3.29 (0.462), interact efficiently with users having 3.23 (0.425), does any work assigned to me having 3.32 (0.541), ability to compete with other library staff having 3.23 (0.669), and always delivers when given tasks.

7) Effect of Leadership Styles Adopted by University Librarians on Staff Productivity

According to the results mentioned in Table 4: indicates that the majority of the respondents agreed that leadership styles of their university librarians affect them in the following ways: Bring about high staff productivity with $3.42(0.620)$, make the staff have morale for work with $3.06(0.680)$, make the staff to make more effective contributions to the library with 3.03 (0.706), make the staff receptive to change and innovation with 3.06 (0.574), and eliminate laziness among the staff with $2.74(0.815)$. Though, majority of the respondents disagreed that leadership styles adopted by University Librarians bring about low staff productivity with 2.48 (1.029). A close look at the result presented in Table 4 , that shows the majority of the respondents agreed that leadership style adopted in their university libraries brings about high staff productivity (item statement 19) as it records the highest mean score with (that is 3.42).

8) Factors Militating Against Staff Productivity in the University Libraries

In Table 5: result shows that majority of the respondents completely agreed with all the item statements as constituting the factors that militate against staff productivity. These factors as found out, include: the leadership style adopted by University Librarians having 3.48 (0.626), absence of working incentives having 3.42 (0.564), stress in work place having 3.06 (0.964), lack of cordial relationship between boss and staff having 3.29 (0.588), inadequate exposure of staff to modern trends having 3.35 (0.755), and poor working environment having 3.71 (0.461). Nonetheless, a look at the responses shows that poor working environment and leadership style, which are item statements 30 and 25, among other 
Table 3. Rate of staff productivity of librarians in the university libraries.

\begin{tabular}{lcccccccc}
\hline S/N & Item Statements & $\begin{array}{c}\text { SA } \\
(\%)\end{array}$ & $\begin{array}{c}\mathrm{A} \\
(\%)\end{array}$ & $\begin{array}{c}\mathrm{D} \\
(\%)\end{array}$ & $\begin{array}{c}\text { SD } \\
(\%)\end{array}$ & $\begin{array}{c}\text { Mean } \\
\text { dev. }\end{array}$ & $\begin{array}{c}\text { St. } \\
\text { Decision }\end{array}$ \\
\hline 13 & Able to work to the close of work & 45.2 & 54.8 & - & - & 3.45 & 0.506 & Agreed \\
$\mathbf{1 4}$ & Brings new ideas into the library & 9 & 22 & - & - & 3.29 & 0.462 & Agreed \\
15 & Interacts efficiently with users & 22.6 & 77.4 & - & - & 3.23 & 0.425 & Agreed \\
16 & Does any work assigned to me & 35.5 & 61.3 & 3.2 & - & 3.32 & 0.541 & Agreed \\
17 & Ability to compete with other library staff & 32.3 & 61.3 & 3.2 & 3.2 & 3.23 & 0.669 & Agreed \\
18 & Always delivers when given a task & 35.5 & 51.6 & 12.9 & - & 3.23 & 0.669 & Agreed \\
\hline
\end{tabular}

Table 4. Effect of leadership styles adopted by university librarians on staff productivity.

\begin{tabular}{|c|c|c|c|c|c|c|c|c|}
\hline $\mathrm{S} / \mathrm{N}$ & Item Statements & $\begin{array}{l}\text { SA } \\
(\%)\end{array}$ & $\begin{array}{c}\mathrm{A} \\
(\%)\end{array}$ & $\begin{array}{c}\mathrm{D} \\
(\%)\end{array}$ & $\begin{array}{l}\text { SD } \\
(\%)\end{array}$ & Mean & $\begin{array}{l}\text { St. } \\
\text { dev. }\end{array}$ & Decision \\
\hline 19 & $\begin{array}{l}\text { Leadership styles adopted in my university } \\
\text { library bring about high staff productivity }\end{array}$ & 48.4 & 45.2 & 6.5 & - & 3.42 & 0.62 & Agreed \\
\hline 20 & Bring about low staff productivity & 19.4 & 29 & 32.3 & 19.4 & 2.48 & 1.029 & Disagreed \\
\hline 21 & Make the staff have morale for work & 22.6 & 64.5 & 9.7 & 3.2 & 3.06 & 0.68 & Agreed \\
\hline 22 & $\begin{array}{l}\text { Make the staff to make more } \\
\text { effective contribution to the library }\end{array}$ & 25.8 & 51.6 & 22.6 & - & 3.03 & 0.706 & Agreed \\
\hline 23 & $\begin{array}{l}\text { Make the staff receptive to change } \\
\text { and innovation }\end{array}$ & 19.4 & 67.7 & 12.9 & - & 3.06 & 0.574 & Agreed \\
\hline 24 & Eliminate laziness among the staff & 12.9 & 58.1 & 19.4 & 9.7 & 2.74 & 0.815 & Agreed \\
\hline
\end{tabular}

Table 5. Factors militating against staff productivity in the university libraries.

\begin{tabular}{|c|c|c|c|c|c|c|c|c|}
\hline $\mathrm{S} / \mathrm{N}$ & Item Statements & $\begin{array}{l}\text { SA } \\
(\%)\end{array}$ & $\begin{array}{c}\mathrm{A} \\
(\%)\end{array}$ & $\begin{array}{c}\mathrm{D} \\
(\%)\end{array}$ & $\begin{array}{l}\text { SD } \\
(\%)\end{array}$ & Mean & $\begin{array}{l}\text { St. } \\
\text { dev. }\end{array}$ & Decision \\
\hline 25 & $\begin{array}{c}\text { The leadership style adopted by } \\
\text { the University Librarians }\end{array}$ & -54.8 & -38.7 & -6.5 & - & 3.48 & 0.626 & Agreed \\
\hline 26 & Absence of working incentives & -45.2 & -51.6 & -3.2 & - & 3.42 & 0.564 & Agreed \\
\hline 27 & Stress in work place & -38.7 & -38.7 & -12.9 & -9.7 & 3.06 & 0.964 & Agreed \\
\hline 28 & $\begin{array}{c}\text { Lack of cordial relationship } \\
\text { between boss and staff }\end{array}$ & -35.5 & -58.1 & -6.5 & - & 3.29 & 0.588 & Agreed \\
\hline 29 & $\begin{array}{l}\text { Inadequate exposure of staff } \\
\text { to modern trends }\end{array}$ & -48.4 & -41.9 & -6.5 & -3.2 & 3.35 & 0.755 & Agreed \\
\hline 30 & Poor working environment & -71 & -29 & - & - & 3.71 & 0.461 & Agreed \\
\hline
\end{tabular}

factors were strongly agreed and rated high by majority of the respondents as factors that militate against staff productivity in the libraries studied.

\section{Conclusion}

This overall study looked at University employees called Librarians' leadership styles (autocratic, democratic, and transformational) and employees' productiv- 
ity in designated university libraries in Jamshoro City, Sindh Province, Pakistan. The study was born out of the passion of the researchers to examine if the pattern of the leadership of the top management of university libraries in Jamshoro Education City totally affects the productivity of their subordinates that are working under their kind supervision. This study started by initially bearing in mind the leadership styles adopted by these top management authorities and found the implementation of autocratic, democratic, and transformational leadership styles. It was still, clearly recorded that the transformational style was exceedingly adopted, followed by the democratic style. This study also observed the proportion of staff productivity and also recorded impressive proportion in different areas, particularly their ability to work to the close of work, bringing new ideas, among other things. Considering the effects of leadership style adopted by the University Librarians on the staff of the library, the study recorded high and numerous positive effects ranging from high staff productivity, effective contributions to the library, to eliminate laziness among staff, among other effects. Finally, this research study sought to uncover the factors militating against staff productivity in selected libraries in Imo State and recorded poor working environment and the leadership style of the University Librarian, among other factors. Based on the findings of the study, the study concludes that University Librarians' leadership styles have a great effect and influence on staff productivity. This is to say that if the pattern of leadership exhibited by the University Librarians pleases and allows the staff under them to contribute their quota, the issue of working environment would be enhanced, thereby promoting the rate of staff productivity in their libraries.

\section{Recommendations}

- University employees called here Librarians should make the creation of good working environment, a total priority. They should embrace the feedback mechanism and appreciate them by adopting the qualities of a good leader.

- University Librarians should adopt leadership styles (autocratic, democratic and transformational) that will allow their subordinates to make their input. They should intensify effort in carrying along all staff under them and manifest motherly or fatherly love to all.

- Library authorities and management should provide incentives for staff of the library.

- University Librarians should appreciate and grant free working days to their staff.

- Efforts should be made by University Librarians and library authorities to provide the staff with adequate exposure to modern trends.

\section{Conflicts of Interest}

The authors declare no conflicts of interest regarding the publication of this paper. 


\section{References}

Aina, L. O. (2016). Library and Information Science Text for Africa. Third World Information Services, Ibadan.

Akparobore, D., \& Omosekejimi, A. F. (2020). Leadership Qualities and Style: A Panacea for Job Productivity and Effective Service Delivery among Library Staff in Academic Libraries in South, Nigeria. Emerald: Library Management, 41, 677-687. https://doi.org/10.1108/LM-02-2020-0025

Azeez, R. O., Jayeoba, F. I., \& Adeoye, A. O. (2016). Job Satisfaction, Turnover Intention and Organizational Commitment. BVIMSR's Journal of Management Research, 8, 102-114.

Bandhanpreet, K., Mohindru, A., \& Pankaj, M. (2013). Antecedents of Turnover Intentions: A Literature Review. Global Journal of Management and Business Studies, 3, 1219-1230.

Belete, A. K. (2018). Turnover Intention Influencing Factors of Employees: An Empirical Work Review. Journal of Entrepreneurial Organization Management, 7, 253-267.

Caglar, D., \& Duarte, C. (2019). 10 Principles of Workforce Transformation, Organizations \& People (Magazine). Strategy+Business. https://www.strategy-business.com/

Germano, M. A. (2010). Leadership Style and Organizational Impact. Library Work Life. http://ala-apa.org/newsletter/2010/06/08/spotlight/

Idiegbeyan-Ose, J., Opeke, R., \& Nwokeoma, N. M. (2018). Influence of Organizational Culture on Turnover Intention of Library Staff in Private University Libraries, South-West Nigeria. Academy of Strategic Management Journal, 17, 1-16.

Igbaekemen, G. O., \& Odivwri, J. E. (2015). Impact of Leadership Style on Organization Performance: A Critical Literature Review. Arabian Journal of Business and Management Review, 5, 1-7.10.

Kouzes, J. M., \& Posner, B. Z. (2002). The Leadership Challenge. Jossey-Bass.

Kumar, R. R. (2011). Turnover Issues in the Textile Industry in Ethiopia: A Case of Arba Minch Textile Company. African Journal of Marketing Management, 3, 32-44.

Long, C. S., Thean, L. Y., Ismail, W. K. W., \& Jusoh, A. (2012). Leadership Styles and Employees' Turnover Intention: Exploratory Study of Academic Staff in a Malaysian College. World Applied Science Journal, 19, 575-581.

Omeluzor, S. U., Dolapo, P. G., Agbawe, M. O., Onasote, A. O., \& Abayomi, A. I. (2017). Library Infrastructure as Predictor of Turnover Intentions of Librarians in University Libraries in Nigeria. Information Impact: Journal of Information and Knowledge Management, 8, 1-12. https://doi.org/10.4314/iijikm.v8i1.1

Pearce II, J. A., \& Robinson, R. B. (2005). Strategic Management. A.J.T.B.S. Publishers.

Purwanto, A., Primahendra, R., Sopa, A., Kusumaningsih, S., \& Pramono, R. (2020). Pengaruh Gaya Kepemimpinan Transformational, Authentic, Authoritarian, Transactional Terhadap Kinerja Guru Madrasah Aliyah di Tangerang. EVALUASI: Journal Management Pendidikan Islam, 4, 20-44. https://doi.org/10.32478/evaluasi.v4i1.342

Segun-Adeniran, C. D. (2015). Leadership Styles and Job Productivity of University Library Staff: Interrogating the Nexus. Library Philosophy and Practice (e-Journal). http://digitalcommons.unl.edu/libphilprac/1269

Wilson, D. E. (2020). Moving toward Democratic-Transformational Leadership in Academic Libraries. Emerald: Library Management, 41, 731-744.

https://doi.org/10.1108/LM-03-2020-0044 